$47,7 \%$ men). Mean age 68,94(SD 11,38) in lymphomas and 71,46(SD 11,24) in leukemias. Age-adjusted rate during the period for lymphoma was $152,19 / 10^{5}$ inhab/year (92,05 women and 240,14 men). Lymphoma age-adjusted rate increased from $52,46 / 10^{5}$ inha/year in 1999 to 187,57 in 2015, both women (from 42,74 to 142,95 ) and men (from 280,77 to 326,63 ). An annual increase in lymphoma rate of $6,9 \%$ is estimated (RRI 1,069; Cl 95\% 1,054-1,085). Age-adjusted rate during the period for leukemia was $90,87 / 10^{5}$ inhab/year $(37,09$ women and 144,65 men). Leukemia age-adjusted rate increased from $18,86 / 10^{5}$ inhab/year in 1999 to 94,05 in 2015, both women (13,80 in 1999 to 65,93 in 2015) and men $(38,70$ in 1999 to 204,84 in 2015$)$. An annual increase in leukemia rate of $8,2 \%$ is estimated (RRI 1,083; CI 95\% 1,069-1,097).

Conclusions: In Spain from 1999-2015 lymphoma and leukemia hospital admissions in RA patients increased, with an estimation of $6,9 \%$ and $8,2 \%$ annual increase respectively.

Disclosure of Interest: None declared

DOI: 10.1136/annrheumdis-2018-eular.4831

\section{SAT0142 PULMONARY HYPERTENSION AMONG HISPANIC PATIENTS WITH RHEUMATOID ARTHRITIS: A CASE- CONTROL STUDY}

J. R. Azpiri-López ${ }^{1}$, D. A. Galarza-Delgado², I. J. Colunga-Pedraza² , J. A. DávilaJiménez $^{1}$, E. E. Abundis-Márquez ${ }^{2}$, A. H. Guillén-Lozoya ${ }^{2}$, F. J. Torres-

Quintanilla $^{1}$, R. E. Ramos-Cázares ${ }^{2}$, R. Vera-Pineda ${ }^{1}$, J. A. Cárdenas-de la

Garza ${ }^{2} .{ }^{1}$ Cardiology, ${ }^{2}$ Rheumatology, Hospital Universitario "Dr José E. Gonzalez", UANL, Monterrey, Mexico

Background: Rheumatoid arthritis (RA) is a chronic, systemic, inflammatory, multifactorial disease that mainly affects synovial joints. Pulmonary artery hypertension (PAH) can appear as a complication of connective tissue diseases. It is possible that pulmonary artery systolic pressure (PASP) in RA may be elevated due to interstitial lung disease, pulmonary vasculitis, pulmonary veno-occlusive disease, or cardiac disease (1). Although right heart catheterization is the gold standard, Doppler echocardiography has proved to be a reliable non-invasive method for detecting PAH (2).

Objectives: To determine the prevalence of PAH in RA patients and compare it to matched controls.

Methods: A case-control study with RA patients aged 40 to 75 years that fulfilled the 2010 ACR/EULAR criteria and matching controls were included. Exclusion criteria: poor acoustic window, absence of tricuspid regurgitation (TR), prior atherosclerotic cardiovascular (CV) disease and overlap syndromes. Patients were matched using age, sex and comorbidities. Transthoracic echocardiogram was performed by a board-certified cardiologist. PASP was calculated using the Bernoulli equation: TR velocity ${ }^{2} \times 4+$ right atrial pressure according to ASE's guidelines. We used Denton's definition of PAH on Doppler echocardiography as an estimated PASP $>30 \mathrm{mmHg}(3)$

Results: A total of 76 RA patients and 52 matched controls were included. Demographic and clinical characteristics of both groups are shown on table 1. As shown on table 2, the mean PASP was higher RA patients $(27.14 \pm 6.34 \mathrm{mmHg})$ than controls $(24.68 \pm 5.44 \mathrm{mmHg})(P=0.024)$. $\mathrm{PASP} \geq 30 \mathrm{mmHg}$ prevalence was significantly higher in RA patients ( $34.2 \%$ vs $11.5 \% ; P=0.004)$.

Table 1 Demographic characteristics

\begin{tabular}{llll}
\hline & \multicolumn{2}{l}{ RA } & \multicolumn{2}{l}{$P$} \\
\cline { 2 - 3 } & $(\mathrm{n}=76)$ & $(\mathrm{n}=52)$ & 0.041 \\
\hline Women, $\mathrm{n}(\%)$ & $74(97.4)$ & $46(88.5)$ & 0.195 \\
Age, mean \pm SD & 55.71 & 53.86 & \\
BMI, mean \pm SD & \pm 8.84 & \pm 6.14 & 0.343 \\
Hypertension, $\mathrm{n}(\%)$ & 29.11 & 28.31 & 0.176 \\
Type 2 Diabetes mellitus, $\mathrm{n}$ & \pm 5.42 & \pm 4.37 & 0.612 \\
(\%) & $26(34.2)$ & $12(23.1)$ & \\
Active smoking, $\mathrm{n}(\%)$ & $8(10.5)$ & $7(13.5)$ & 0.487 \\
\hline
\end{tabular}

Table 2 Echocardiographic findings

\begin{tabular}{|c|c|c|c|}
\hline & RA & Control & $P$ \\
\hline & $(n=76)$ & $(n=52)$ & \\
\hline $\begin{array}{l}\text { TR Vmax } \\
(\mathrm{m} / \mathrm{s}), \\
\text { mean } \pm S D\end{array}$ & $2.27 \pm 0.32$ & $2.18 \pm 0.33$ & 0.157 \\
\hline PASP & 27.14 & 24.68 & 0.024 \\
\hline $\begin{array}{l}(\mathrm{mmHg}) \\
\text { mean } \pm S D\end{array}$ & \pm 6.34 & \pm 5.44 & \\
\hline $\begin{array}{l}P A S P \geq 30 \\
m m H g, n\end{array}$ & $\begin{array}{l}26 \\
(34.2 \%)\end{array}$ & $6(11.5 \%)$ & 0.004 \\
\hline
\end{tabular}

TR Vmax - Tricuspid regurgitation maximum velocityConclusions: Elevated PASP, suggesting $\mathrm{PAH}$, was more prevalent on RA patients than controls. A higher number of CV events that cannot be explained by traditional risk factors have been reported in RA patients; and it is possible that the elevation in the PASP could contribute to the problem. Prospective studies are needed to evaluate the role of elevated PASP in morbidity and mortality of RA patients.

\section{REFERENCES:}

[1] Panagiotidou E, et al. Rheumatoid arthritis associated pulmonary hypertension. Respir Med Case Reports 2017;20:164-7.

[2] Udayakumar $\mathrm{N}$, et al. Pulmonary hypertension in rheumatoid arthritis-Relation with the duration of the disease. Int J Cardiol 2008;127(3):410-2.

[3] Denton CP, et al. Comparison of Doppler Echocardiography and Right Heart Catheterization To Assess Pulmonary Hypertension in Systemic Sclerosis. Br J Rheumatol 1997;36:239-43.

Disclosure of Interest: None declared

DOI: 10.1136/annrheumdis-2018-eular.7184

\section{SAT0143 THE ARREST OF BONE MINERAL DENSITY LOSS AT THE LUMBAR SPINE AND HIP IN PATIENTS WITH ACTIVE RHEUMATOID ARTHRITIS DURING RITUXIMAB THERAPY}

K. Keywani ${ }^{1,2}$, H. G. Raterman ${ }^{1,2,3}$, M. M. ter Wee ${ }^{1,4}$, M. T. Nurmohamed ${ }^{1,2}$, A. E. Voskuyl ${ }^{1}$, I. E. Bultink ${ }^{1}$, W. F. Lems ${ }^{1,2} .{ }^{1}$ Rheumatology and immunology Center, VU University Medical Center, ${ }^{2}$ Rheumatology and immunology Center, Reade, Amsterdam, ${ }^{3}$ Rheumatology, North West Clinics, Alkmaar, ${ }^{4}$ Epidemiology and Biostatistics, VU University Medical Center, Amsterdam, Netherlands

Background: One of the well-known characteristics of rheumatoid arthritis (RA) is generalized bone loss. ${ }^{1-2}$ Although rituximab is a frequently prescribed biologic disease-modifying anti-rheumatic drug (bDMARD) for the treatment of RA, data regarding changes in bone mineral density $(B M D)$ in $R A$ patients during rituximab therapy are limited.

Objectives: To study the extent of BMD loss at lumbar spine and hip in patients with active rheumatoid arthritis treated with rituximab.

Methods: Consecutive RA patients with an active disease status (DAS28>3.2) starting rituximab treatment were enrolled in a prospective cohort study. BMD of the lumbar spine and hip was measured before treatment and after one year using dual energy X-ray absorptiometry (DXA) to assess BMD changes. Clinical response was defined using the European League Against Rheumatism (EULAR) response criteria.

Results: A total of 43 subjects (18.6\% men) with mean age of 53.6 (SD 10.7) years were included in the study. Median disease duration was 9.5 (IQR 0.740.2) years and baseline mean DAS28 was 5.6 (SD 1.3). In responders, the DAS28 decreased with 1.97 points (SD 0.78) $95 \% \mathrm{Cl} 1.67-2.28 \mathrm{p}<0.001$; and in non-responders, the DAS28 decreased with 0.01 points (SD 0.67 ) $95 \% \mathrm{Cl}-0.35-$ $0.37 \mathrm{p}=0.945$. All changes in BMD were not statistically significant (table 1 ).

Table 1 BMD change after one year categorized by EULAR response

\begin{tabular}{lcccc}
\multicolumn{7}{l}{ Table 1 BMD change after one year categorized by EULAR response } \\
\hline & $\begin{array}{c}\text { Mean (SD) } \\
\text { baseline BMD }\end{array}$ & $\begin{array}{c}\text { Mean (SD) } \\
\text { follow-up BMD }\end{array}$ & $\begin{array}{c}\text { Mean } \\
\text { change }\end{array}$ & $\begin{array}{c}\% \\
\text { change }\end{array}$ \\
\hline LS total ( $\mathrm{n}=43$ ) & $1.015(0.182)$ & $1.011(0.186)$ & -0.004 & -0.4 \\
LS responders $(\mathrm{n}=27)$ & $1.026(0.169)$ & $1.017(0.182)$ & -0.009 & -1.0 \\
LS non-responders $(\mathrm{n}=16)$ & $0.997(0.206)$ & $1.001(0.198)$ & 0.004 & +0.7 \\
Hip total $(\mathrm{n}=43$ ) & $0,845(0.144)$ & $0,849(0.143)$ & 0.003 & +0.5 \\
Hip Responders $(\mathrm{n}=27)$ & $0.836(0.126)$ & $0.838(0.129)$ & 0.003 & +0.3 \\
Hip Non-responders $(\mathrm{n}=16)$ & $0.862(0.174)$ & $0.867(0.166)$ & 0.005 & +0.8 \\
\hline BMD is presented in $\mathrm{g} / \mathrm{cm}^{2}$; BMD; bone mineral density; LS, lumbar spine.
\end{tabular}

Conclusions: The findings of this study indicate that patients with active RA treated with rituximab have arrest of bone loss at both the lumbar spine and hip. Moreover, these results suggest that rituximab has bone-saving abilities even in the absence of clinical response.

\section{REFERENCES :}

[1] Mclnnes IB, et al. The New England journal of medicine 2011;365:22052219.

[2] Firestein GS, et al. Nature 2003;423:356-361.

Disclosure of Interest: None declared

DOI: 10.1136/annrheumdis-2018-eular.4827 